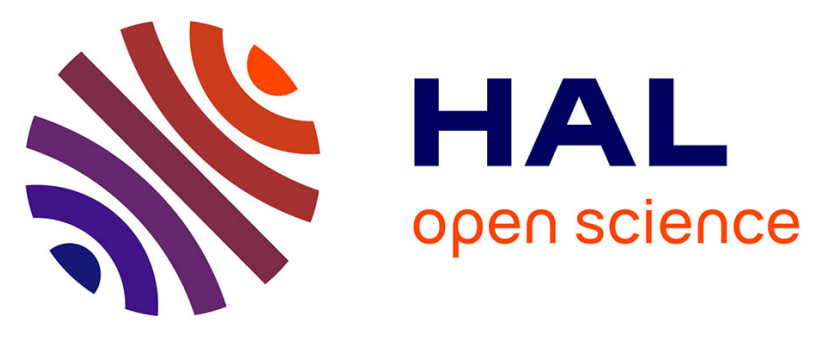

\title{
Three-Electrode Analytical and Preparative Electrochemistry in Micro-Volume Hanging Droplets
}

Ana Isabel Perez Jimenez, Lylian Challier, Margherita Di Pisa, Manon

Guille-Collignon, Frédéric Lemaître, Solange Lavielle, Christelle Mansuy,

Christian Amatore, Eric Labbé, Olivier Buriez

\section{To cite this version:}

Ana Isabel Perez Jimenez, Lylian Challier, Margherita Di Pisa, Manon Guille-Collignon, Frédéric Lemaître, et al.. Three-Electrode Analytical and Preparative Electrochemistry in Micro-Volume Hanging Droplets. Electrochemistry Communications, 2015, 54, pp.41-45. 10.1016/j.elecom.2015.02.013 . hal-01136026

\section{HAL Id: hal-01136026 \\ https://hal.sorbonne-universite.fr/hal-01136026}

Submitted on 26 Mar 2015

HAL is a multi-disciplinary open access archive for the deposit and dissemination of scientific research documents, whether they are published or not. The documents may come from teaching and research institutions in France or abroad, or from public or private research centers.
L'archive ouverte pluridisciplinaire HAL, est destinée au dépôt et à la diffusion de documents scientifiques de niveau recherche, publiés ou non, émanant des établissements d'enseignement et de recherche français ou étrangers, des laboratoires publics ou privés. 


\section{Three-Electrode Analytical and Preparative Electrochemistry in Micro-Volume Hanging Droplets}

Ana Isabel PEREZ JIMENEZ ${ }^{1}$, Lylian CHALLIER ${ }^{1}$, Margherita DI PISA ${ }^{2}$, Manon GUILLECOLLIGNON $^{1}$, Frédéric LEMAîTRE ${ }^{1}$, Solange LAVIELLE ${ }^{2}$, Christelle MANSUY ${ }^{2}$, Christian AMATORE ${ }^{1}$, Eric LABBÉ ${ }^{1}$, Olivier BURIEZ ${ }^{1 *}$

${ }^{1}$ Ecole Normale Supérieure - PSL Research University, Département de Chimie, Sorbonne Universités - UPMC Univ. Paris 06, CNRS UMR 8640 PASTEUR, 24 rue Lhomond, 75005 Paris, France.

${ }^{2}$ Sorbonne Universités, UPMC Univ Paris 06, LBM, 4, Place Jussieu, 75005 Paris, France, Ecole Normale Supérieure - PSL Research University, Département de Chimie, CNRS, UMR 7203 LBM.

Abstract. Three-electrode micro-cells equipped with a conventional reference electrode (SCE) were easily constructed based on micro-volume droplets suspended by capillary forces to the fritted glass of the SCE bridge. Working and counter electrodes were simply inserted through the droplet surface, allowing classical electrochemistry to be readily performed in minute samples.

Keywords. Electroanalysis; Micro-volume; Droplet; Platinization; Cell-penetrating peptide

Acknowledgements. We thank J. Palomo for the SEM micrographs. This work was supported by the CNRS (UMRs 8640 and 7203), the Ecole Normale Supérieure, Université P. et M. Curie, and the Agence Nationale de la Recherche (grant number: ANR-12-BS08-0002-01 "ELIPTIC"). The authors also thank Conacyt for support of A.I.P.J. 


\section{Introduction.}

Miniaturization of analytical techniques is an important issue for samples of low availability and for the development of portable devices, as well as for evident economic and ecological reasons (consumption of small amounts of precious and/or expensive reagents, waste production). Within this framework, electrochemistry brings a significant contribution to the analysis in small volumes, notably through the miniaturization of electrodes [1]. On the other hand, the development of microfabrication techniques such as photolithography [2-7], screen printing [8, 9], plasma etching [10], and laser ablation [11, 12] allowed the preparation of volume-limited structures. In this context, two main approaches have been developed aimed at running electrochemistry in small volumes. The first one, essentially developed in view of the detection of small numbers of molecules released by single cells, consists in the immersion of needle-type micro-electrodes in small chambers, or vials, prepared by micro-fabrication techniques $[2,3,13,14]$. Alternatively, the second route deals with the immersion of needle-type micro-electrodes within droplets, or meniscus, thus avoiding the preparation of containers $[15,16,17]$. This approach has been implemented with micro-, nano-, picoand femto-liter droplets deposited either on a substrate or onto the electrode itself.

Micro volume droplets are generally deposited onto the working electrode surface [18, 19]. However, comparatively large liquid-solid reference electrode (e.g. SCE) cannot be immersed in such drops. Instead, pseudo-reference wire-shaped electrodes such as $\mathrm{Ag}, \mathrm{Ag} / \mathrm{AgCl}$, or Pt are used though they suffer from potential instability with some species $[20,21,22]$.

Herein, a new approach is proposed for real three-electrode operation with a commercial SCE in micro-volume droplets combined to smaller counter and working electrodes. This allows investigating both aqueous and organic solutions provided a chamber is used to prevent evaporation. Actually, the novelty of this device relies on the fact that droplets are deposited neither on a substrate nor on the working electrode surface, but suspended at the fritted glass of a bridge compartment in which the SCE is placed (Figure 1A). The bridge was aimed at preventing any contamination of the reference electrode from the solution and vice versa. This original electrochemical cell was shown to be perfectly adapted to electroanalysis of low quantities of highvalued molecules and also for controlled-potential electrolysis. 


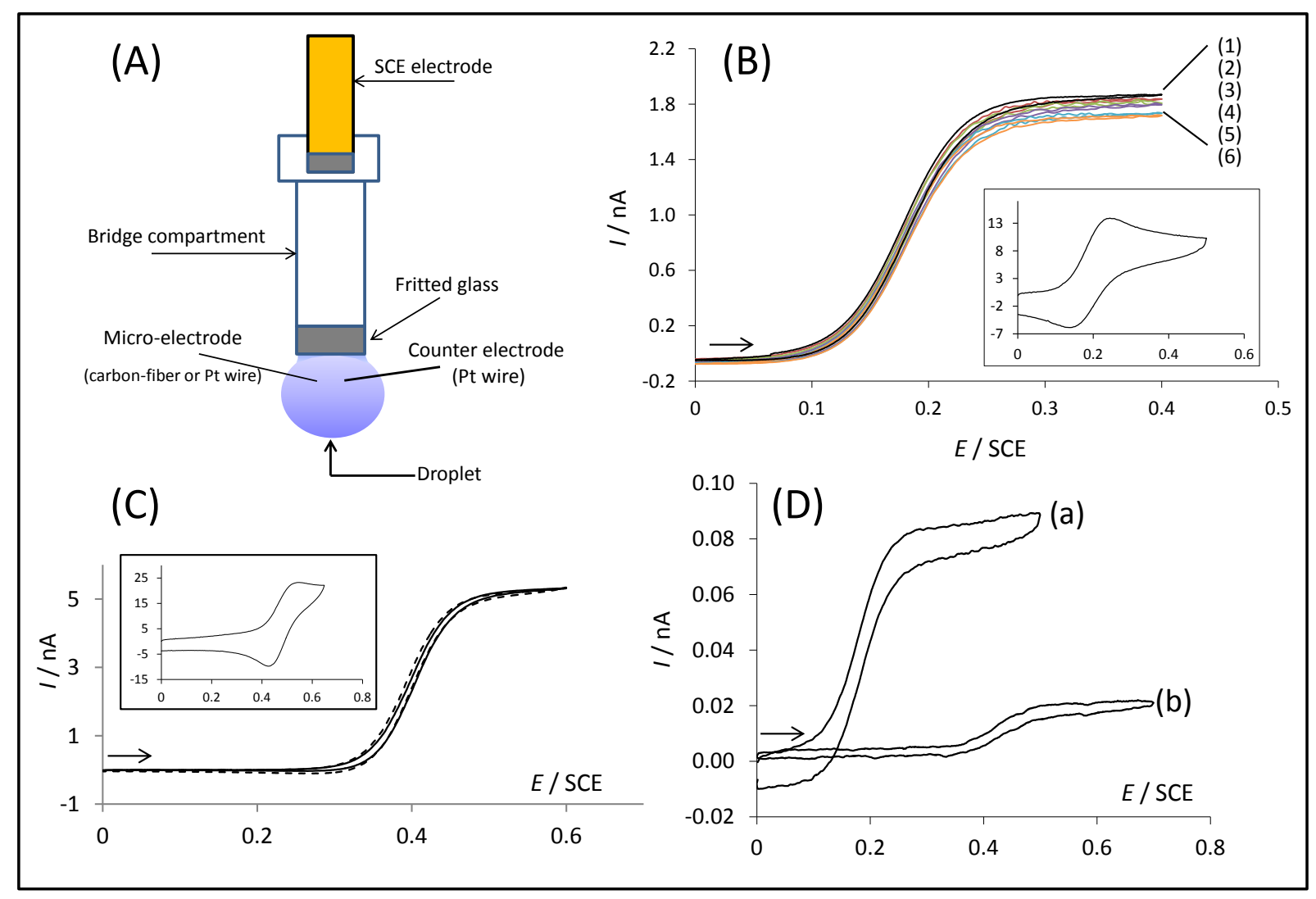

Figure 1.

(A) Experimental device used to perform cyclic voltammetry and controlled-potential electrolysis in $50 \mu \mathrm{L}$ hanging droplets. Note that a U-shape bridge compartment could be also used in order to have the droplet deposited on the fritted glass surface rather than hanging from the latter.

(B) Voltammetry of ferrocenemethanol $(0.5 \mathrm{mM})$ in $\mathrm{H}_{2} \mathrm{O}+\mathrm{KCl}(0.1 \mathrm{M})$ at a $10 \mu \mathrm{m}$ diameter carbonfiber electrode $(\mathrm{v}=20 \mathrm{mV} / \mathrm{s})$. The same curve (1) was obtained in the droplet or in bulk solution or after cleaning the electrode surface. Curves (2) to (6) corresponded to successive scans run after 2, 3, 8,13 , and 15 minutes, respectively, in the micro-volume cell. Inset shows a voltammogram obtained at $20 \mathrm{~V} / \mathrm{s}$ in the droplet.

(C) Voltammetry of ferrocene $(1 \mathrm{mM})$ in $\mathrm{DMF}+n \mathrm{Bu}_{4} \mathrm{PF}_{6}(0.1 \mathrm{M})$ at a platinum electrode after 15 minutes in the droplet (dotted line) and in a bulk solution (solid line). $\mathrm{v}=20 \mathrm{mV} / \mathrm{s}$. Inset shows a voltammogram obtained in the droplet at $20 \mathrm{~V} / \mathrm{s}$.

(D) Voltammetry of (a) ferrocenemethanol $(25 \mu \mathrm{M})$ and of (b) Fc-(Arg) $(50 \mu \mathrm{M})$ in PBS at a $10 \mu \mathrm{m}$ diameter carbon-fiber electrode in the droplet $(v=20 \mathrm{mV} / \mathrm{s})$. 


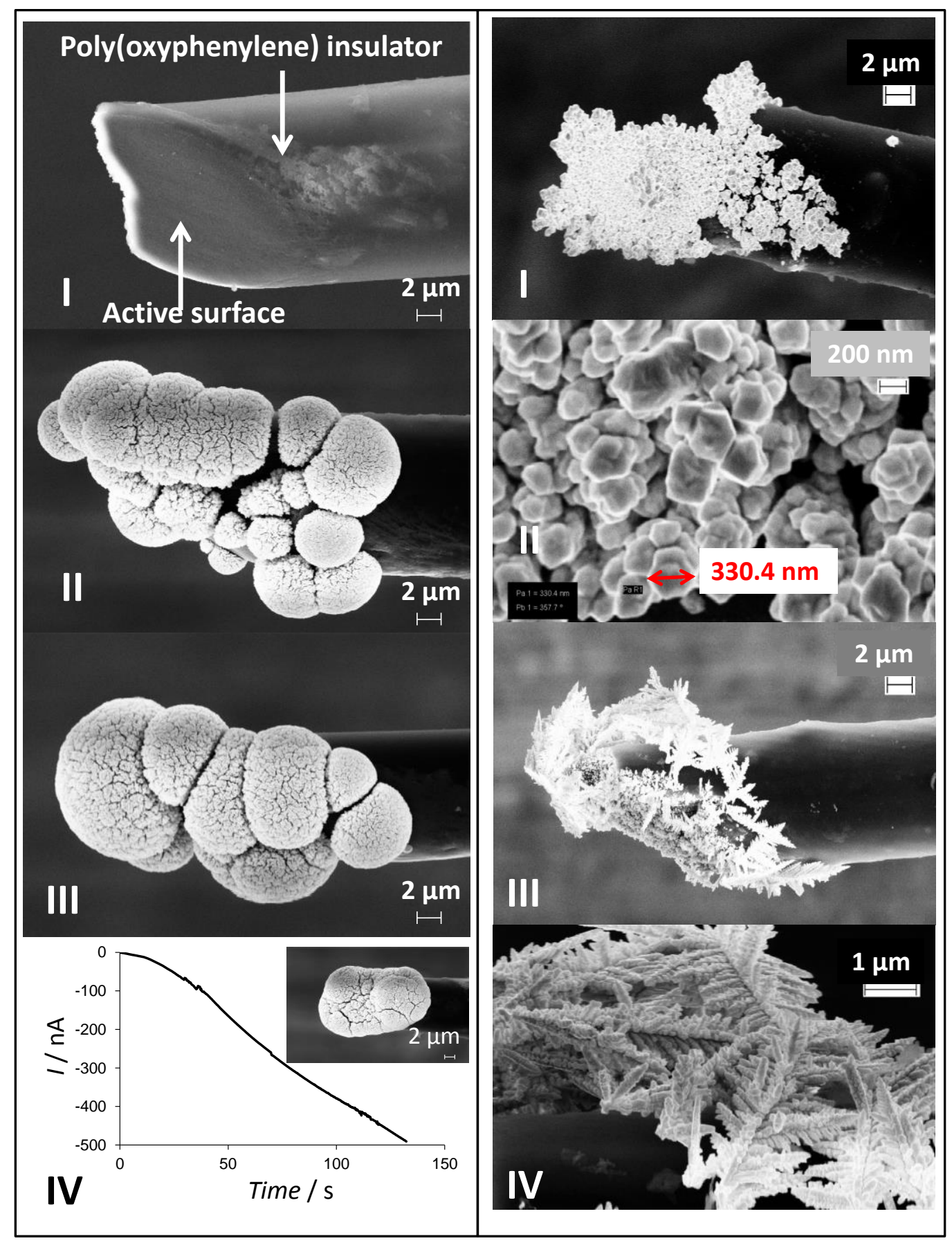

\section{Figure 2.}

Left: Scanning electron microscopy images of a carbon fiber (10 $\mu \mathrm{m}$ in diameter) electrode obtained before (I) and after a platinization charge of $20 \mu \mathrm{C}$ (II) and $40 \mu \mathrm{C}$ (III) within the droplet. In (IV) is shown a typical evolution of the amperometric current recorded during the reduction ( $E=-65$ $\mathrm{mV} / \mathrm{SCE})$ of hydrogen hexachloroplatinate(IV) $(28 \mathrm{mM})$ in the presence of lead acetate $(0.57 \mathrm{mM})$. The electrodeposition started at $\mathrm{t}=0$ and was pursued until reaching a platinization deposit $(30 \mu \mathrm{C}$ in this case); inset shows the corresponding platinum deposit.

Right: Scanning electron microscopy images of a $10 \mu \mathrm{m}$ gold modified carbon fiber electrode by reduction of potassium tetrachloroaurate(III) $(2.6 \mathrm{mM})$ dissolved in sulfuric acid $(0.1 \mathrm{M})$. Images (I) and (II) were obtained after reduction at $+400 \mathrm{mV} / \mathrm{SCE}$ for 30 seconds. (III) and (IV) were obtained after reduction at $-500 \mathrm{mV} / \mathrm{SCE}$ for 30 seconds. 


\section{RESULTS AND DISCUSSION}

\section{Cyclic Voltammetry in Water and in Organic solvent}

Cyclic voltammograms of ferrocenemethanol were first recorded at a carbon fiber electrode immersed in a suspended $50 \mu \mathrm{L}$ water droplet to test and validate the device under steady-state and transient conditions. Usual sigmoidal- and peak-shaped voltammograms were obtained at slow and high scan rates, respectively (Figure 1B). Identical voltammograms were obtained in a bulk solution $(3 \mathrm{~mL})$ of same composition upon using the same electrodes demonstrating that, in microliter volumes, voltammetric responses are not affected by depletion phenomena as observed in pico-liter cells [15]. Furthermore, it was calculated that $4.82 \mathrm{mC}$ would be required to completely electrolyze $50 \mu \mathrm{L}$ of $1 \mathrm{mM}$ ferrocenemethanol. Considering a steady-state current of ca. $4 \mathrm{nA}$ flowing during 25 seconds, i.e., ca. $0.1 \mu \mathrm{C}$ passed, only about $2.10^{-3} \%$ of the analyte was oxidized during one slow scan. This confirms that depletion of ferrocenemethanol in the drop can be disregarded even at slow scan experiments.

Another important point to test was evaporation. It was already reported that evaporation from an air-exposed $1 \mu \mathrm{L}$ aqueous droplet was significant after around 60 seconds (peak currents increased by more than 5\%) [23]. Since relative evaporation rate is proportional to the surface-to-volume ratio of the sample, no evaporation, and therefore no peak current increase, was expected under our conditions within tens of minutes. Conversely, a very slight peak current decrease was observed with time (Figure 1B). This was due to the fouling of the electrode surface. Indeed, the initial peak current value was recovered after polishing the electrode (Figure 1B), and no evidence of evaporation was observed after 15 minutes exposure to air.

Organic solvent droplets could be suspended as well to the bridge fritted glass. Cyclic voltammetry of ferrocene was therefore performed in dimethylformamide or acetonitrile with a platinum microelectrode (the shaft of the above carbon-fiber was insulated by poly(oxyphenylene) which may dissolve in organic solvents). To prevent solvent evaporation, a tissue soaked with the same organic solvent was placed into the measurement chamber. An argon stream saturated with solvent was also gently blown before starting each experiment, for five minutes, to remove oxygen from the chamber. Transient and stationary voltammograms were recorded at high $(20 \mathrm{~V} / \mathrm{s})$ and slow $(20 \mathrm{mV} / \mathrm{s}) \mathrm{scan}$ rates, respectively (Figure $1 \mathrm{C}$ ). As observed in water, the electrochemical responses were identical to those obtained in a bulk solution $(3 \mathrm{~mL}$ ) and no solvent evaporation was noted during 15 minutes at least, in agreement with previous reports [23].

\section{Controlled-potential electrolysis}

The presence of a saturated calomel electrode in our device is particularly relevant to perform accurate controlled-potential electrolysis in micro volumes. Since the anode and cathode were in close proximity (few millimeters) any electrolysis of a reversible redox soluble couple would have led to redox cycling. For this reason, we considered the reduction of $\mathrm{H}_{2} \mathrm{PtCl}_{6}$ or $\mathrm{KAuCl}_{4}$ in aqueous solutions as test experiments. A series of controlled-potential electrolyses were run in suspended 50 $\mu \mathrm{L}$ water droplets, instead of usual milliliter volumes [24], as a function of the charge passed and analyzed by SEM (Figure 2). Platinization of the carbon-fiber microelectrode was successfully achieved. SEM images show that platinization occurred only on the active surface but not on the insulated one. Also, no interference of the counter electrochemical reaction was observed within the short time-scale electrodeposition (estimated maximum diffusion layer thickness c.a.: $0.5 \mathrm{~mm}$ ). A typical variation of the amperometric current following the reduction of hydrogen 
hexachloroplatinate(IV), in the presence of lead acetate, on the carbon-fiber active surface is shown in Figure 2(IV)-left.

Similarly, electrodeposition of gold nanocrystals could be achieved onto carbon-fiber electrode surfaces. In Figure 2-right are shown the SEM images obtained after reduction of potassium tetrachloroaurate for 30 seconds at either +400 or $-500 \mathrm{mV} /$ SCE corresponding to the plateau and the foot of $\mathrm{KAuCl}_{4}$ reduction wave, respectively. As already demonstrated on glassy carbon electrodes [25], the size, structure, and distribution of gold nanocrystals depended on the overpotential, illustrating the benefit of the three-electrode cell operation.

\section{Electrochemical detection of a high value-added molecule}

Owing to its minute volume our method is perfectly suited for electroanalysis of precious/poorly available molecules. This was illustrated through the detection of a cationic cell-penetrating peptide (CPP) grafted to a ferrocenyl ( $\mathrm{Fc}$ ) moiety. Presently, CPPs are among the most popular and efficient shuttle to access the intracellular medium owing to their ability to penetrate cell membranes at micromolar concentrations without causing significant membrane damages while carrying biologically active cargoes (drugs, oligonucleotides, proteins, nanoparticles, etc.) [26, 27]. For these reasons, they have opened new avenues for therapeutic applications, notably in cancer therapy [28, 29]. Though fluorescence-based techniques are the most commonly exploited approaches to detect these peptides [30,31], electrochemical methods may also be of great analytical interest. In this context, we recently reported on the modification of a cationic CPP with a ferrocenyl unit [32]. However, these experiments required large CPP amounts (milliliter electrochemical cell and millimetric sized electrodes). Hence, the electrochemical detection of a CPP composed of nine arginines and tagged with a ferrocenyl unit (noted as Fc-( $\left.\mathrm{Arg})_{9}\right)$ at a carbon fiber electrode immersed in a micro-volume suspended water droplet was investigated. As shown in Figure 1D, a well-defined sigmoidal voltammogram was obtained at slow scan rate in the presence of micromolar concentration of the Fc- $(\mathrm{Arg})_{9}$ peptide. Also, the $\mathrm{Fc}-(\mathrm{Arg})_{9}$ oxidation appeared at a more positive potential value than that of ferrocenemethanol illustrating an electron-withdrawing effect of the amino acids [33]. This again illustrated the analytical interest of the present three-electrode droplet cell approach.

\section{Conclusion}

This work established the validity of electrochemical investigations performed in micro-volume hanging droplets, in the presence of a conventional reference electrode. This original approach is simple, low-cost, easy to implement and versatile. Moreover, it does not require any construction of a miniaturized electrochemical cell, thus affording immediate electrochemical characterization. 


\section{Experimental Section}

Chemicals. Tetra- $n$-butylammonium hexafluorophosphate (Acros Organics) and Potassium chloride (Sigma Aldrich) were used as supporting electrolytes in organic solvents and in highly purified water (HPW; resistivity = $18 \mathrm{M} \Omega . \mathrm{cm}$; Milli-Q system; Millipore, Billerica, MA, USA), respectively. Acetonitrile (Sigma Aldrich), N,N-dimethylformamide (Acros Organics), ferrocene (Fluka), ferrocenemethanol (Aldrich), potassium tetrachloroaurate (Aldrich), sulfuric acid (Sigma-Aldrich), hydrogen hexachloroplatinate (Aldrich), and lead(II) acetate trihydrate (Sigma) were used as received. Phosphate-buffered saline (PBS) pH 7.4 (Gibo, Invitrogen Co.) was prepared with HPW.

Instrumentation. Cyclic voltammetry and controlled-potential electrolysis experiments were performed in a Faraday cage using a Princeton Applied Research potentiostat (PARSTAT 2273). The quality of gold and platinum depositions were monitored by scanning electron microscopy (Eline model by RAITH).

Working Microelectrode Fabrication. Carbon fiber microelectrodes (10 $\mu \mathrm{m}$ diameter, Thornel Carbon Fibers, Cytec Engineered Materials, Greenville, SC, USA) were constructed, insulated and polished as described previously [34].

Platinum working disk-electrodes were made through cross-sections of platinum wires $(25 \mu \mathrm{m}$ diameter, Goodfellow) sealed in a Pyrex glass capillary (Harvard Apparatus, length: $10 \mathrm{~cm}$; outer diameter: $1.2 \mathrm{~mm}$; inner diameter: $0.6 \mathrm{~mm}$ ). Electrodes were polished to a mirror finish with emery paper of decreasing grain size and alumina powder (Minitech 233 by PRESI), sonicated for 10 minutes in HPW, and dried before use.

Electrochemical Experiments. All measurements were made at room temperature. The reference electrode was a commercial saturated calomel electrode (SCE - Radiometer Analytical) equipped with a bridge compartment filled with the same solvent/supporting electrolyte solution as in the drop. The counter electrode was a $1 \mathrm{~cm}$ length platinum wire $(0.5 \mathrm{~mm}$ in diameter, Goodfellow). The working and counter electrodes were held with the help of $\mathrm{H}-7$ pipette holders (Narishige group). Their immersion in the drop was done manually without the help of any micromanipulators. Water and organic solvents droplets $(50 \mu \mathrm{L})$ were dispensed with a Hamilton microsyringe directly on the fritted-glass of the bridge compartment. To avoid any solvent evaporation and/or when an inert atmosphere was required, the drop and electrodes were placed in a glass enclosed chamber in which an argon stream saturated with the corresponding solvent was gently passed during five minutes before starting the experiment. A piece of tissue (TX 604 cellulose/polyester, surface: $2 \mathrm{~cm}^{2}$ ) soaked in the appropriate solvent was also placed in the chamber.

Preparation of Gold-Coated and Platinized Carbon-Fiber Electrodes through Electrolysis. All polished carbon-fiber surfaces were modified by controlled-potential electrolyses after immersion of the electrode in a $50 \mu \mathrm{L}$ droplet of the appropriate solution. Deposition of gold metal at the surface of carbon-fiber electrodes was achieved by reduction of potassium tetrachloroaurate(III) $(2.6 \mathrm{mM})$ dissolved in sulfuric acid $(0.1 \mathrm{M})$, at +400 or $-500 \mathrm{mV}$ vs. SCE. Platinized carbon-fiber electrodes 
were obtained by reducing, at - $65 \mathrm{mV}$ vs. SCE, a solution prepared itself by mixing $1 \mathrm{~mL}$ of hydrogen hexachloroplatinate(IV) (8 wt.\% solution in water) and lead(II) acetate trihydrate $(99.8 \%, 1.6 \mathrm{mg}$ ) in PBS $(6.4 \mathrm{~mL})[35,36]$.

Solid Phase Peptide Synthesis. All standard chemicals and protected amino acids were purchased from Sigma, Merck chemicals Ltd., Carlo Erba or Iris Biotech AG.

The $\operatorname{Arg}_{9}$ sequence was synthesized on a $0.1 \mathrm{mmol}$ scale by conventional $t$ Boc/Tosyl SPPS starting from a MBHA-Resin (0.54 mmol/g loading) on an 431A ABI synthesizer (Applied Biosystem). Boc$\operatorname{Arg}(\mathrm{Tos})$ (1mmol) was coupled with DCC/HOBt (1eq., 1:1). The dried Boc-peptidyl resin was transferred into a fritted syringe, swollen (NMP) and reacted with ferrocene carboxylic acid (0.5 $\mathrm{mmol})$, HBTU $(0.45 \mathrm{mmol})$, and DIPEA ( $1 \mathrm{mmol})$, in NMP for $30 \mathrm{~min}$. The ferrocene peptidyl-resin was washed (NMP, DCM, MeOH), and dried under vacuum. Then, the peptide was cleaved from the resin with $\mathrm{HF}$ at $0^{\circ} \mathrm{C}$, in the presence of anisole $(1.5 \mu \mathrm{L} / \mathrm{mg}$ of resin), for 2 hours. Elution with a $10 \%$ acetic acid solution afforded the crude peptide, which was purified by RP-HPLC (5-30\% B in 30 minutes, VP $250 \times 16 \mathrm{~mm}$ NUCLEODUR ${ }^{\circ} \mathrm{C} 18$ HTec $5 \mu \mathrm{m}$ column working at $14 \mathrm{~mL} / \mathrm{min}$, with the solvent systems: A $\left(0.1 \%\right.$ TFA in $\left.\mathrm{H}_{2} \mathrm{O}\right)$ and $\mathrm{B}\left(0.1 \%\right.$ TFA in $\left.\mathrm{CH}_{3} \mathrm{CN}\right)$, and UV detection at 220 and $280 \mathrm{~nm}$. Characterization of Fc-(Arg) 9 : i) Analytical RP-HPLC: 8.48min, purity over 95\% (5-30\% B in 10 minutes, Proto $200 \mathrm{C} 18-3 \mu \mathrm{m} 100 \times 4.6 \mathrm{~mm}$ column at $1 \mathrm{~mL} / \mathrm{min}$ (Higgins Analytical)); ii) MALDI-TOF MS (DEPro, $A B I)$ in positive ion reflector mode using the $\mathrm{CHCA}$ matrix $(\mathrm{m} / \mathrm{z}):[\mathrm{M}+\mathrm{H}]^{+}$calcd 1635.73 ; found, 1635.09 . 


\section{References.}

[1] T. Li, W. Hu, Nanoscale. 3 (2011) 166-176.

[2] R.A Clark, P.B Heitpas, A. G. Ewing, Anal. Chem. 69 (1997) 259-263.

[3] R.A Clark, A. G. Ewing, Anal. Chem. 70 (1998) 1119-1125.

[4] C. D. T. Bratten, P. H. Cobbold, J. M. Cooper, Anal. Chem. 69 (1997) 253-258.

[5] C. D. T. Bratten, P. H. Cobbold, J. M. Cooper, Anal. Chem. 70 (1998) 1164-1170.

[6] A. F. Dias, G. Dernick, V. Valero, M. G. Yong, C. D. James, H. G. Craighead, M. Lindau, Nanotechnology. 13 (2002) 285-289.

[7] P. Chen, B. Xu, N. Tokranova, X. J. Feng, J. Castracane, K. D. Gillis, Anal. Chem. 75 (2003) 518-524.

[8] A. Hayat, J.-L. Marty, Sensors. 14 (2014) 10432-10453.

[9] Li, M.; Li, Y.-T.; Li, D.-W.; Long, Y.-T. Anal. Chim. Acta. 734 (2012) 31-44.

[10] J. S. Rossier, C. Vollet, A. Carnal, G. Lagger, V. Gobry, H. H. Girault, P. Michel, F. Reymond, Lab Chip. 2 (2002) 145-150.

[11] J. C. Ball, D. L. Scott, J. K. Lumpp, S. Daunert, J. Wang, L. G. Bachas, Anal. Chem. 72 (2000) 497501.

[12] J. C. Ball, J. K. Lumpp, S. Daunert, L. G. Bachas, Electroanalysis. 12 (2000) 685-690.

[13] Troyer K.P.; Wightman, R.M. Anal. Chem. 74 (2002) 5370-5375.

[14] N. Gao, M. Zhao, X. Zhang, W. Jin, Anal. Chem. 78 (2006) 231-238.

[15] R. Kashyap, M. Gratzl, Anal. Chem. 70 (1998) 1468-1476.

[16] K. Yum, H.N. Cho, J. Hu, M.-F. Yu, ACSNano. 1 (2007) 440-448.

[17] T.S. Miller, J.V. Macpherson, P.R. Unwin, J. Electroanal. Chem. 729 (2014) 80-86.

[18] K.W. Willman, R. Murray, Anal. Chem. 55 (1983) 1139-1142.

[19] U. Schröder, J.D. Wadhawan, R.G. Compton, F. Marken, P.A.Z. Suarez, C.S. Consorti, R.F. de Souza, J. Dupont, New. J. Chem. 24 (2000) 1009-1015.

[20] R. A. B. da Silva, A.C. Rabelo, R.A.A. Munoz, E.M. Richter, Electroanalysis. 22 (2010) 2167-2171.

[21] M.W. Shinwari, D. Zhitomirsky, I.A. Deen, P.R. Selvaganapathy, M.J. Deen, D. Landheer, Sensors. 10 (2010) 1679-1715.

[22] M.E. Clark, J.L. Ingram, E.E. Blakely, W.J. Bowyer, J. Electroanal. Chem. 385 (1995) 157-162.

[23] W.J. Bowyer, M.E. Clark, J.L. Ingram, Anal. Chem. 64 (1992) 459-462.

[24] C. Amatore, S. Arbault, Y. Bouret, B. Cauli, M. Guille, A. Rancillac, J. Rossier, ChemPhysChem. 7 (2006) 181-187.

[25] M.O. Finot, G.D. Braybrook, M.T. McDermott, J. Electroanal. Chem. 466 (1999) 234-241.

[26] P. Järver, Ü. Langel, Biochim. Biophys. Acta. 1758 (2006) 260-263.

[27] S. El-Andaloussi, T. Holm, Ü. Langel, Current Pharmaceutical Design. 11 (2005) 3597-3611. 
[28] S.B. Fonseca, M.P. Pereira, S.O. Kelley, Adv. Drug. Deliv. Rev. 61 (2009) 953-964.

[29] A. Bolhassani, Biochim. Biophys. Acta. 1816 (2011) 232-246.

[30] T. Holm, S.E. Andaloussi, in: Ü. Langel (Ed.), Cell-Penetrating Peptides: Methods and Protocols, Methods in Molecular Biology, vol. 683, 2011, p. 207 (Chapter 15).

[31] M. Magzoub, A. Gräslund, Quarterly Reviews of Biophysics. 37 (2004) 147-195

[32] P. Messina, G. Hallais, E. Labbé, M. Béranger, G. Chassaing, S. Lavielle, C. Mansuy, O. Buriez, C. Amatore, Electrochim. Acta. 80 (2012) 180-186.

[33] H.-B. Kraatz, D. M. Leek, A. Houman, G.D. Enright, J. Lusztyk, D.D.M. Wayner, J. Organomet. Chem. 589 (1999) 38-49.

[34] S. Arbault, P. Pantano, J. A. Jankowski, V. M., C. Amatore, Anal. Chem. 67 (1995) 3382-3390.

[35] Y. Ikariyama, S. Yamauchi, T. Yukiashi, H. Ushioda, J. Electroanal. Chem. Interfacial Electrochem. 251 (1988) 267-274.

[36] C. Amatore, S. Arbault, C. Bouton, K. Coffi, J.C. Drapier, H. Ghandour, Y.H. Tong, ChemBioChem. 7 (2006) 653-661. 